\title{
Regionalism in the World Polity
}

Joseph Jupille, University of Colorado, joseph.jupille@colorado.edu Brandy Jolliff, University of Colorado, brandy.jolliff@colorado.edu

\begin{abstract}
Preferential and regional trade agreements (PTAs and RTAs) are increasingly ubiquitous and uncertainly effective in the trade regime. We develop a "world polity" account of the emergence of PTAs and RTAs that accounts for the surprisingly high degrees of isomorphism (structural identity) and decoupling (goal-achievement mismatch) so readily observable in this field. After elaborating its implications for the EU, less developed countries (LDCs) and regionalism, we identify a handful of testable implications. Though our aim is primarily theoretical, we offer empirical explorations of these hypotheses. Regionalism, we argue, has become a line in the "script of modernity" which tells other actors how to organize themselves, what goals to seek, and how to behave. These actors, in turn, embrace this newlyscripted expectation as a function of their need for external legitimation and exposure to the carriers of world societal scripts. We expect these world polity factors to complement, rather than substitute for, standard political economy determinants of PTA and RTA formation.
\end{abstract}

Prepared for EUSA 2011 Biennial Meetings, Boston. 


\section{Introduction}

The rise of preferential and regional trade agreements (respectively, PTAs and RTAs) stands as one of the signal institutional changes in the global trade regime in the last two decades. A suitable explanation of this development must account for at least three empirical observations, all of which are depicted in Figure 1. First, as in the top-left panel, it must account for the explosive growth in preferential trade agreements since the early post-Cold War period. ${ }^{1}$ Second, it must account for variation in the adoption of this particular institutional form across actors in the international system. The enthusiastic embrace of regionalism by both the European Union (EU) (the modal entry in the topright panel) and, increasingly, developing countries (bottom-left panel), in particular, call out for explanation. Third, any suitable explanation of PTAs and RTAs in the contemporary period must account for its dys- or at least a-functionality, a feature illustrated by the bottom-right panel's portrayal of African regionalism. ${ }^{2}$ What accounts for the sudden, widespread, uneven and functionally ambiguous embrace of the institutional form of PTAs/RTAs in the contemporary world?

Our goal in this paper is primarily theoretical. We elaborate a "world polity" account of regionalism, which we believe offers coherent and plausible accounts of all three key observations. We seek to summarize world polity theory, apply its logic to the organizational field of preferential/regional trade, and draw out its observable implications for the promotion and embrace of these suddenly ubiquitous, but questionably effective, institutional forms. The empirics we bring to bear will be illustrative, rather than evaluative. But our hunch is that a world polity account of regionalism merits a

\footnotetext{
${ }^{1}$ Source: http://www.wto.org/english/tratop e/region e/regfac e.htm. We think of RTAs as trade agreements among neighbors that have plurilateral $(N>3)$ membership. Much of what the WTO illustrates in this graph involves bilateral agreements that may or may not be among proximate countries, and hence does not technically qualify for the label of RTA. Because we will only use these data illustratively, we hope the reader will indulge the elision. ${ }^{2}$ Source: http://www.rovingbandit.com/2010/03/spaghetti-bowl-of-african-regional.html. A comment at the blog from which the image was sourced indicates that the figure is in error because Rwanda and Burundi are members of the East African Community (EAC), a claim which is confirmed at the EAC's official website (http://www.eac.int/). If the graphic was indeed generated by World Bank staff, this error speaks directly to our point, which is that the membership distribution of African regionalism is exceedingly complex.
} 
central place in our scholarly toolkits as we seek to account for institutional change in the international system.

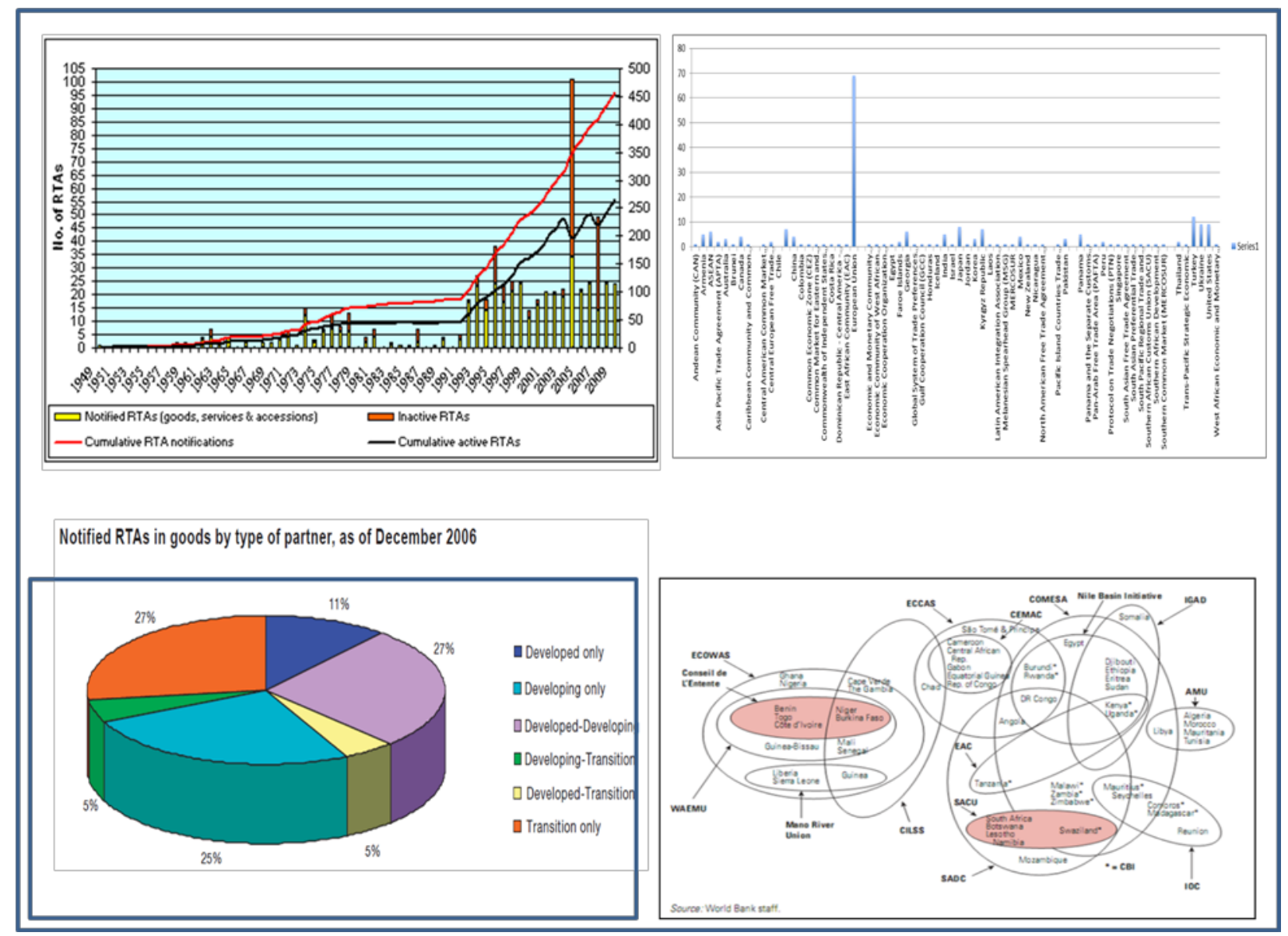

Figure 1. Patterns of Regionalism.

We proceed in four parts. Part II introduces world polity theory and augments it with symbolic interactionist insights that are relevant to the embrace of societal norms and forms by actors with problematic identities. Part III offers further conceptual elaboration, with particular attention on the European Union (EU) and less developed countries (LDCS) insofar as they relate to regionalism. This section ends with a few generic hypothesis that might form the object of empirical evaluation. Part IV offers some cursory empirical explorations of these hypotheses. Part V summarizes and concludes.

\section{Institutions, Interactions and Identities}

\section{A. World Polity Theory}


For over thirty years, Stanford sociologist John Meyer, his colleagues and students have been elaborating and empirically documenting the nature and consequences of a "world polity" or a "world society" in which a common cultural logic, grounded in quintessentially modern and Western precepts of liberalism and rational agency, defines universal conceptions of actorhood and action. This "world polity theory" ${ }^{3}$ departs and seeks to account for two key empirical observations.

First, the modern world displays an astonishing degree of isomorphism -identity of structureof individuals, organizations and states. Across radically different circumstances -historical and cultural contexts, resource endowments, relative prices, problem profiles, task demands and functional requirements-actors, purposes, action and organization are understood and structured in identical ways (Meyer 1995, p. x). Individuals are conceived as rational agents endowed with rights and competent to act autonomously; organizations are populated (or at least advised) by credentialed professionals and characterized by rational, scientific and specialized bureaucratic arrangements and decisionmaking; and states enact identical programs and policies (all emphasizing development, progress, rights and responsibilities) through precisely the same organigrammatic arrangements (Meyer et al. 1997, 158). Individuals, organizations and states are joined by many other actors (professional associations, non-governmental organizations [NGOs], etc.), all of whom share the "authorized agentic capability" necessary to actorhood (Meyer and Jepperson 2009 [2000], 111). It is nearly impossible to imagine that all of this invariance reflects "rational choices by existentially given actors having inexplicably similar agendas" (Boli and Thomas 1999, 5). Instead it reflects, in the world polity view, a universally shared culture, encoded in a "script of modernity" from which everyone is reading.

The modern script demands "actorhood" of its readers, and hence, in Meyer's view, the "first 'interest' or problem of the modern actor is not to accomplish prior goals of some sort, but to be an

\footnotetext{
${ }^{3}$ This body of work has gone under numerous more and less helpful guises and labels, including "the world polity approach," "world cultural theory," "sociological institutionalism," and many others. It has been profiled "in full form and detail for the first time" in a recent volume (Krücken and Drori 2009, 3) which uses the "world society theory" label. We maintain the "world polity" label in this paper.
} 
actor" (Meyer 2009 [2000], 160). Organizations are thereby "driven to incorporate the practices and procedures defined by prevailing rationalized concepts of organizational work and institutionalized in society. Organizations that do so increase their legitimacy and their survival prospects, independent of the immediate efficacy of the acquired practices and procedures" (Meyer and Rowan 2009 [1977], 89, 97). "Organizations are rewarded for being similar to other organizations in their fields" (DiMaggio and Powell 1983, 153) in other ways, as well. "Similarity can make it easier for organizations to transact with other organizations ... and to fit into administrative categories that define eligibility for public and private grants and contracts" (DiMaggio and Powell 1983, 153). Overall, then, there are "tremendous premiums" associated with conforming to ("reading from") the script (Meyer 2009 [2000], 160). Actors are willing to make "exorbitant and utterly unrealistic claims" (Meyer 2009 [2000], 160) about who they are and what they do, all in pursuit of world-societal approval, legitimation and other benefits.

Second, as a consequence and at the same time, world polity theorists postulate a profound degree of "decoupling", or disjuncture, between ritually embraced forms and goals and everyday action. Many political scientists and IR specialists will be familiar with this concept from Krasner's importation of the notion of "organized hypocrisy" from organizational theory. The core idea here is that actors embrace, articulate, embody and enact extravagant claims about their competencies and (i.e., their actorhood) in ways that are consistent with the demands of the global script, but not necessarily consistent with their task environments, functional capacities, or overall capabilities. "Decoupling is endemic," Meyer tells us, "because [actors] are modeled on an external culture that cannot simply be imported wholesale as a fully functioning system" (Meyer et al. 1997, 154). Actors must give "legitimate demonstrations of actorhood." The "establish their [very] existence by adopting common forms and supporting the creation of such common forms" (Meyer 2009 [2000], 160).

Three sorts of implications arise from this general tendency toward decoupling. First, actors and organizations will fail to realize their stated goals and to live up to their stated and embodied self- 
conceptions and -projections. Promise will not be matched by performance. Second, rather than responding to such performative shortcomings by "lowering their sights" and making less extravagant claims, actors have a tendency "double down" in reasserting their institutionally-legitimate natures, programs and plans. They undertake ritualized "activities celebrating institutionalized rules", even though these are positively costly (efficiency reducing) and bear opportunity costs in terms of practical performance foregone. They thus "routinely devote resources to maintaining the most admired identity claims, however implausible these may be" (Meyer 2010, 12), as these are "virtuous ceremonial expenditures" necessary to establishing and maintaining high-flying identity claims (Meyer and Rowan 2009 [1977], 103). Since "preferred models of the modern actor celebrate cooperative and virtuous actorhood even more than successful actorhood," more attention may be paid to the assertion of identity than to the effective and efficient pursuit of practical policies and programs (Meyer 2010, 11). Third, related, policy failures (in achieving stated goals, such as development or "progress") should not necessarily be "analyzed as mistakes, temporary dysfunctions, instances of corrupt or manipulative suboptimization," nor necessarily be seen as "sources of stress and instability" (Meyer 2010, 13). They can be quite intentional (or at least tolerable), enduring and unproblematic.

In sum, the Meyerian institutional account departs from the observation of astonishing degrees of actor isomorphism (identical structuring) and decoupling (a tolerated mismatch between stated identities and aims and actual performance). On its face, regionalism fits the pattern: it is widespread, often embodying the ambitions hopes and dreams of those adopting it, but its performance and results, while still largely ambiguous, seem likely to be highly decoupled, to fall far short of these stated aspirations. In Meyerian sociology, "formal structures of many organizations ... dramatically reflect the myths of their institutional environments instead of the demands of their work activities" (Meyer and Rowan 2009 [1977], 90). 
There are many ways to criticize such an account. We focus on a few key theoretical and (related) empirical issues. First, theoretically, Meyer's macrosocial worldview leaves us a little bit in the blind as to the particular circumstances of a given actor's isomorphizing choices and tolerance of decoupling. He suggests some mechanisms that might underpin them beyond cultural stuff floating around in the ether and being aspirated and embodied, for example by discussing actors' desire for legitimation. But, theoretically, constants are encountering constants. Meyer does not give us much to go on in terms of what might drive variation in isomorphism and decoupling. No real account, except for "modernity", is given of the content of the social script from which actors read - it is taken as selfevidently given. Second, empirically, Meyer and his acolytes have generated massive amounts of support for the claims identified just above, but this evidence tends to take descriptive form. Isomorphism and decoupling are widespread, which is certainly consistent with world polity theory (though we note that the theory was born partly in response to these observations). But Meyerians have had a harder time telling us why this is the case, in terms of causal mechanisms. Consistent evidence can confirm theory, but then the theory was devised in view of the same evidence, and when we confront constants with constants, empirical work generates only marginal payoffs. Third, there really is very little agency in Meyer's account -quite ironically, since the script of modernity only considers as actors those that have agency. Meyerians view "action as the enactment of broad institutional scripts rather than a matter of ... autonomous choice, motivation and purpose" (Meyer, Boli and Thomas 2009 [1987], 68). But, as Finnemore $(1993,1996)$ argues and demonstrates, sometimes someone (e.g., international organizations) stands behind and pushes isomorphic institutional change, while others calculate about whether to engage in it. Overall, in our view, as applied to regionalism world polity theory requires a good set of microfoundations, more attention to mechanisms, and more exploration of (sources) of variation. We argue that Erving Goffman's "symbolic interactionism”, when brought into dialogue with the Meyerian account, can go some way toward providing these. 


\section{B. Symbolic Interaction and Problematic Identity}

Erving Goffman theorizes the social-psychology of human interaction. People, according to Goffman, take up roles similar to those of actors on a stage when participating in human interaction. In any interpersonal exchange, there are two points of view, that of the individual attempting to express herself, and that of the "other", who gains an impression of the expressive individual. Individuals will inevitably attempt to manipulate the impression they give off according to the audience they wish to impress, thus, "it is only in the world of social interaction that the objects about which [others] make inferences will purposely facilitate and hinder this inferential process," (Goffman, 1959, p. 3).

Furthermore, in such situations, the individual attempting to express herself in an acceptable manner to the other will do so as a function of the definition of the structural situation at hand. Thus, for example, we might expect a first or second year graduate student to frequently invoke the surnames and works of well-known scholars in seminar discussions, so that they may impress their professors and achieve good standing in the course. In addition, situations of interaction often have a moral character, whereby "society is organized on the principle that any individual who possesses certain social characteristics has a moral right to expect that others will value and treat [them] in an appropriate way," (Goffman, 1959, p. 13). What can be concluded from this is that not only are individuals constantly seeking to portray themselves in very specific ways in varying social situations ("presentations of self"), but that also if such impressions are successfully developed, they can expect a moral reward in the form of respect and admission to society.

Most of the time, in well-established societies, interaction occurs in highly structured settings in which the script is unproblematic and taken for granted and actors roles and expected behaviors are clear. Given the highly socialized nature of actors in (this aspect of) Goffman's theory, "symbolic interaction" is relatively unproblematic. When you call me on the telephone, we find ourselves on situationally familiar ground, implying that our roles and expected (scripted) behaviours are clear. In the 
United States, I say "hello" when answering the phone. You greet me in turn, state your name and give the reason for your call. I respond by acknowledging who you are and addressing, in good faith, the issue that you have raised by your call. The body of our conversation may meander, but in an effective conversation it addresses itself, at least minimally, to the reasons underlying the conversation. The ebb and flow of conversation must follow conventions of polite listening, turn-taking, appropriate timing and sequencing of our various interventions, and so forth. The end of the call is also highly scripted, usually involving the ceremonial invocation of well-accepted politeness formulas ("have a nice day") and a closure formulation (e.g., "good-bye") indicating mutual agreement that the interaction produced by your call will end. Overall, as Meyer says, "actors enact as much as they act: what they do is inherent in the social definition of the actor itself" (Meyer, Boli and Thomas 2009 [1987], 75).

Political scientists, focused as we tend to be on power and conflict, do not typically focus on the kinds of ritualized, taken-for-granted interactions of the telephone call sort. Instead, and generally, we and many sociologists find greater interest in what Shibutani $(1986,267-269)$ calls "problematic situations." These may be circumstances in which no script covering the present contingency is available, in which existing scripts do not apply well to the involved actors (or in which actors are uncertain or disagree about which script applies), in which actors' identities are fluid or ambiguous, or in which coordination rituals give way to collaboration dilemmas characterized by mixed or opposing interests. "Taken-for-grantedness" recedes in such situations, and actors must work harder, more consciously, to make interaction successful. Some degree of improvisation and innovation may be required, where available frames are far removed from the interaction at hand. More likely, in a sociological view, is that the actors will attempt to move the interaction onto more familiar and comfortable ground, by invoking shared and well-established frames, by positioning themselves within them, and by ritually proceeding according to the terms of the newly-activated script.

\section{Implications for LDCs, EU and Regionalism}


We focus on an aspect of Shibutani's "problematic situations" that is particularly relevant to our empirical terrain, involving a relatively novel institutional form (regionalism) and entities whose (Meyerian) actorhood is in doubt or under question. The European Union (EU) and less developed countries (LDCs) have, in different ways, what we will call "problematic identities". They do not quite fit the template of actorhood articulated in the script of modernity. Problematic identities beget problematic situations, which generate a search for solutions among the actors involved. For both actors, we will go on to suggest, regionalism responds to the dilemma of problematic identity. We elaborate the logic for both the EU and for LDCs here.

\section{A. $\underline{E U}$}

While the EU has been acting on the world stage as a substantially autonomous unit in trade and aid policy for decades, in our view it maintains the status of a problematic actor with a problematic identity, where "problematic" connotes not a negative normative evaluation, but a positive evaluation of misfit with the standards of actorhood instantiated by the world society. Being the first truly supranational organization, it is a new phenomenon in the game of actorhood. This generates difficulties for the EU when it tries to look like a state and act like a state, but given that it cannot be (and gain legitimized recognition as) a state. It suffers from an existential sort of capabilitiesexpectations gap (Hill 1993). This looks and sounds a lot like Meyerian decoupling, which is pervasive and can be substantially tolerated. Indeed, Robert Jackson's analysis of "quasi-states" reminds us that while the EU fails to satisfy many of the empirical attributes of statehood, as do many quasi-states in Africa, it may still seek acknowledgement of itself as an actor; such recognition, even ad hoc, may be sufficient to resolve some of the problematic identity of the EU and enhance its legitimacy (Jackson and Rosberg 1982; Jackson 1987, 1990; on EU's recognition seeking, see Jupille and Caporaso 1998; on recognition in general, see Peterson 1982). This desire reflects the "extreme dependence of modern 
actors on wider legitimating models that sustain their actorhood" (Meyer 2009 [2000], 161), an observation Meyer makes about all people, organizations and states.

Legitimacy, of course, is far from a trivial matter: "The urge for formally declared and generally acknowledged legitimacy approaches the status of a constant feature of political life" (Claude 1966, 367; see also Franck 1990). Hence, at some point the hypocrisies and contradictions of actors who do not look and are not behaving "properly" according to the prevailing script, and whose legitimacy is thereby threatened, can become highly problematic. "There are external social rules and requirements for statehood, that a state is supposed to look a certain way and do certain things" (McNeely 1995, 37). Failure to satisfy these criteria calls into question an actor's legitimacy and very identity. At that point, remedial efforts to more tightly couple institutionalized identities and obligations with adequate programs and performance might be called for. Various internal efforts are always pursued for this purpose, so as better to clothe themselves "in the robes of sovereignty" (Jackson 1987, 543). They will readily engage in "ritual enactment of the structure and content of world political models of the nationstate" (Meyer 1987, 57) by creating development agencies and scientific ministries, by holding procedurally democratic elections, by creating navies and school boards, and so on.

Yet, insofar as states confront difficulties in undertaking such domestic corrective action, they must turn to external sources for inspiration material support. For the EU, the option of arranging "correctly" statelike domestic institutions has been tried, but is ineffective. The flag, notwithstanding its Cartesian perfection, fails to inspire loyalty. Its anthem and motto can only be vocalized sotto voce. It can never look like an isomorphic Westphalian state. The EU cannot seek legitimation and recognition in the same way as an LDC, for which formal diplomatic/international legal recognition as a state, and full membership in the UN, stand as real possibilities. Given this limitation, external legitimation must substitute, and the EU will desperately seek other ways to be legitimated as an actor in the key "clubs" of international society. It will present itself as an entity that is equal to legitimate states in the 
international system, at risk of a Walter Hallstein's state dinners incurring a de Gaulle's wrath. It will highlight its action as a single body in trade negotiations, its prowess in giving of foreign aid, and its ability to win seats in powerful IOs like the WTO. It has one further arrow in its quiver: it can try to write its own organizational form into the script of modernity, thereby legitimating its own model and opening possibilities to interact with others who are, in some sense, "like" it. It can do this by promoting regionalism, selling it especially to the most willing customers (others with problematic identities and need for external legitimation, such as LDCs), and beginning to move "interregionally" in a more socially comfortable and familiar world.

In proposing that the EU is in effect selling regionalism through membership in PTAs and RTAs, we suggest that Finnemore's logic and the example of UNESCO selling science bureaucracies may offer considerable explanatory power. Finnemore's story centers upon the premise that international institutions are capable purveyors of norms. Because UNESCO successfully made the case to UN member states that science bureaucracies are something legitimate states should possess, many bought into the idea and established such bureaucracies, even when their interests did not dictate the necessity of science bureaucracies. We argue that the same mechanism is likely occurring in the case of the EU. The EU sells regionalism (or teaches norms of regionalism, in language closer to Finnemore's) to LDCs and other like-minded states who wish to be accepted into the realm of powerful, developed countries; they can do this, the implicit argument goes, by buying into the growing norm of regional memberships (see Finnemore 1993, 1996).

The EU's ontological projection confronts significant challenges, however, not least of which is its world societal delegitimation, relative to the nation-state (Meyer 1987, 53). The present world society creates and sustains states, not European Unions. By teaching its model and altering the script of modernity, the EU can instruct LDCs to adopt its institutional forms, thereby spreading institutional isomorphism. As regionalism becomes an accepted criteria for the world-society, "resistance to world 
models [becomes] difficult because nation-states are formally committed, as a matter of identity," to the goals and policies shared by all states (Meyer et al. 1997, 160).

Why should the EU care about such things, and why does it actively promote regionalism? Some suggest that EU promotion of regionalism represents merely “the EU's specific and internal experience as a regional organization, parlayed as a required form of behaviour for external actors" (Bicchi 2006, 293). We don't disagree, but we offer the world polity as an external complement to this story. Meyer tells us that there are culturally-determined institutions and memberships that states must be party to in order to justifiably be accepted into a modern world polity. This being the case, we can expect states who wish to be accepted as actors in an international political script of modernity will attempt to develop an image of themselves that is acceptable to members of the club, i.e. developed states. However, a key aspect of our theory is not only that states seek membership into the international political society, but that state-like actors will do so as well. Though it is not a Westphalian state, the EU in many operates as a state in international negotiations and transactions. Despite acting like a state, there is a disconnect between what the EU may wish to be and how it is perceived; the EU has an identity crisis. In promoting regionalism, it may, quite simply, be laying down an "identity marker" not only in terms of what values it upholds (Grugel 2004), but in terms of its very status as an actor.

Meyer takes the argument further, writing, "the actors themselves, in their eagerness to demonstrate universality [which is a highly-legitimated property in the modern world culture] put their own models...forward for general emulation" (Meyer, 2009 [2000], 164, emphasis added). In its international activity, the EU wishes to be accepted in the "club" of elite states in the international system. Thus, we believe that in supporting the growth of regionalism, the EU is creating, or supplying, actors like itself with the idea being that as regionalism spreads so does the legitimacy of regional actors. With the rise in legitimate regional groupings and their accepted actorhood in the international political arena, the EU can then be seen as commensurate alongside powerful states. Injecting this kind 
of agency represents an improvement over the Meyer account of myth and ceremony, which tends not to interrogate "how these models arise and whose interests they initially serve. Explicit attention to the genesis of legitimated models ... should answer this question" (DiMaggio and Powell 1983, 157). The EU can be thought of as an "advisory other", helping "proper agents" to conform to the requisite global scripts. The EU has incentives to make its model part of the script in order to legitimate itself (Strang and Meyer 2009 [1993], 142).

If the EU represents a problematic actor with a legitimacy crisis in the international system, it is possible that its attempt to find legitimate space has given rise to a problematic situation. Shibutani (1986) discusses at length the nature and consequence of problematic situations in the social world, or those situations in which there is no "already existing normative framework" with which to deal with the problem at hand, be it a natural disaster, terrorism, erratic behavior, or any manner of social and political conundrums (Shibutani, 1986, p. 267). According to this definition, we argue that the existence of the EU as the world's first economic and increasingly political supranational institution creates a problematic situation for not only itself but for the political world that must interact with it.

If changes in the script of social interaction, or Meyer's script of modernity, are most likely to occur out of the development and resolution of problematic situations, Meyer also gives us reason to think that it is plausible to see regionalism in the form of PTAs as the latest pre-requisite for membership in today's international political script of modernity. According to Meyer, "organizations do often adapt themselves to their institutional contexts, but they often play active roles in shaping those contexts" (Meyer and Rowan 2009 [1977], 96). EU efforts to shape the script will likely take a specific form: "Efforts to mold institutional environments proceed along two dimensions. First, powerful organizations force their immediate relational networks to adapt to their structures and relations. Second, powerful organizations attempt to build their goals and procedures directly into society as 
institutional rules" (Meyer and Rowan 2009 [1977], 96). Thus, we can expect the EU as a problematic actor to attempt to alter the script in just such a way.

\section{B. $\underline{\text { LDCS }}$}

While, as a set, LDCs vary tremendously on just about every relevant dimension except, by construction, levels of development, in our view they broadly share the status of problematic actors with problematic identities. "Problematic" connotes not a negative normative evaluation, but a positive statement about the misfit between a given identity and the standards of actorhood instantiated by the world society. LDCs are often relatively new to the actorhood game, as with post-colonial states only independent since the middle-third of the 20th century. As we have already discussed, like all states they are isomorphic with their institutional environment. Yet, empirically, they are less likely successfully to enact the programs, and hence achieve the substantive results, that are validated, endorsed and promoted by the world society. These failures can occur in terms of educational attainment of the society, levels of economic development, the establishment of the rule of law, respect for human rights, and consolidation of democracy.

This combination of ambitious models of actorhood and a history of falling short of the attendant promises and expectations is a perfect example of decoupling. In Meyer's world, such decoupling is pervasive and can be substantially tolerated. Indeed, Robert Jackson's analysis of “quasistates" reminds us that many LDCs fail to satisfy any of the empirical attributes of statehood, but still benefit from "juridical statehood" by dint of recognition as states in international society, which alone, he argues, is sufficient to establish and sustain their statehood (Jackson and Rosberg 1982; Jackson 1987, 1990). This certainly speaks to the "extreme dependence of modern actors on wider legitimating models that sustain their actorhood" (Meyer 2009 [2000], 161), an observation Meyer makes about all people, organizations and states. 
Failure to satisfy stated criteria for actorhood calls into question an actor's legitimacy and very identity. This is far from a trivial matter: "The urge for formally declared and generally acknowledged legitimacy approaches the status of a constant feature of political life" (Claude 1966, 367). Hence, at some point the hypocrisies and contradictions of states who are not behaving properly as states, and whose legitimacy is thereby threatened, can become highly problematic. "There are external social rules and requirements for statehood, that a state is supposed to look a certain way and do certain things" (McNeely 1995, 37). Having failed to respect these rules and requirements, LDCs must contemplate remedial efforts to more tightly couple institutionalized identities and obligations with adequate programs and performance. Various internal efforts are always pursued for this purpose, so that LDCs can better clothe themselves "in the robes of sovereignty" (Jackson 1987, 543). They will readily engage in "ritual enactment of the structure and content of world political models of the nation-state" (Meyer $1987,57)$ by creating development agencies and scientific ministries, by holding procedurally democratic elections, by creating navies, school boards, stock markets, and so on. Yet, insofar as states confront difficulties in undertaking such domestic corrective action, they must turn to external sources for inspiration material support.

Stringing all of the above together allows us to summarize our understanding of the "demand" for regionalism among LDCs. ${ }^{4}$ First, like all states they are formed and operate in deeply institutionalized and profoundly influential "world polity." Like all states, they become isomorphic with the institutional templates that exist within that society: they look and attempt to act "as 'real' state should. But because this externally generated script can be only incompletely internally implemented, decoupling arises, as it does in all states. Decoupling may be especially problematic in LDCs because capacity and implementation deficits will make conformity and effective performance hard, all while precarious "problematic identities" will exacerbate legitimacy problems and induce redoubled efforts to recouple

\footnotetext{
${ }^{4}$ We don't want the language of "demand" to imply any particular level of agency or intentionality. We'd like to leave that as an empirical question.
} 
aims and practices. LDCs will thus eagerly adopt the institutional forms outlined in the script of modernity, and will be more acutely concerned to tightly couple form and practice whenever and wherever they can. The script of modernity, in turn, has changed to include a general line about states' needs to form and join IGOs and a specific line about the inclusion of the regional institutional form in their membership portfolios. As a result of this, LDCs embrace, or "demand," regionalism.

\section{Hypotheses}

Combining Meyerian world polity theory with symbolic interactionism generates a series of observable implications over isomorphic institutional change over time and across actors. We outline these as a series of hypotheses.

- Hypothesis 1: changing elite/scientific discourses produce isomorphic institutional change (Meyer).

- Hypothesis 2: the greater an actor's exposure to the carriers of global cultural scripts, the greater its embrace of the institutional forms prevailing in the script of modernity (DiMaggio and Powell 1983, 155; Strang 1990, McNeely 1995; Meyer 2010, 10, 13).

- Hypothesis 3: the more problematic an actor's identity, the more readily it should embrace the institutional forms prevailing in the script of modernity (Meyer 2010, 14).

- Hypothesis 4: the more problematic an actor's identity, the more it should promote adoption of its own model as a new line in the script of modernity.

\section{Empirical Explorations}

\section{A. Hypothesis 1}

In the world polity view, global culture is carried by rationalized, scientific elites. The world polity research program has documented a large number of specific lines in the script of modernity, including basic bureaucratic governmental and administrative forms; the existence of ministries tasked with progress in specific areas such as education, environmental protection, economic development, 
social affairs, military protection; maintenance of elections, and so on. Connie McNeely (1995) has extended this perspective to state membership and participation in intergovernmental organizations (IGOs). We believe that a further line about regionalism - "though shalt form and join regional trade agreements (RTAs)" - now scripts the roles and behaviors of actors in the world polity.

We undertake a very simple exploration of hypothesis 1, which implies that changes in the discourses of scientific elites prefigure isomorphic institutional change. To tap these discourses, we generated a Google Ngram of the frequency with which the term "regionalism" appeared in books published between 1800 and 2000 .

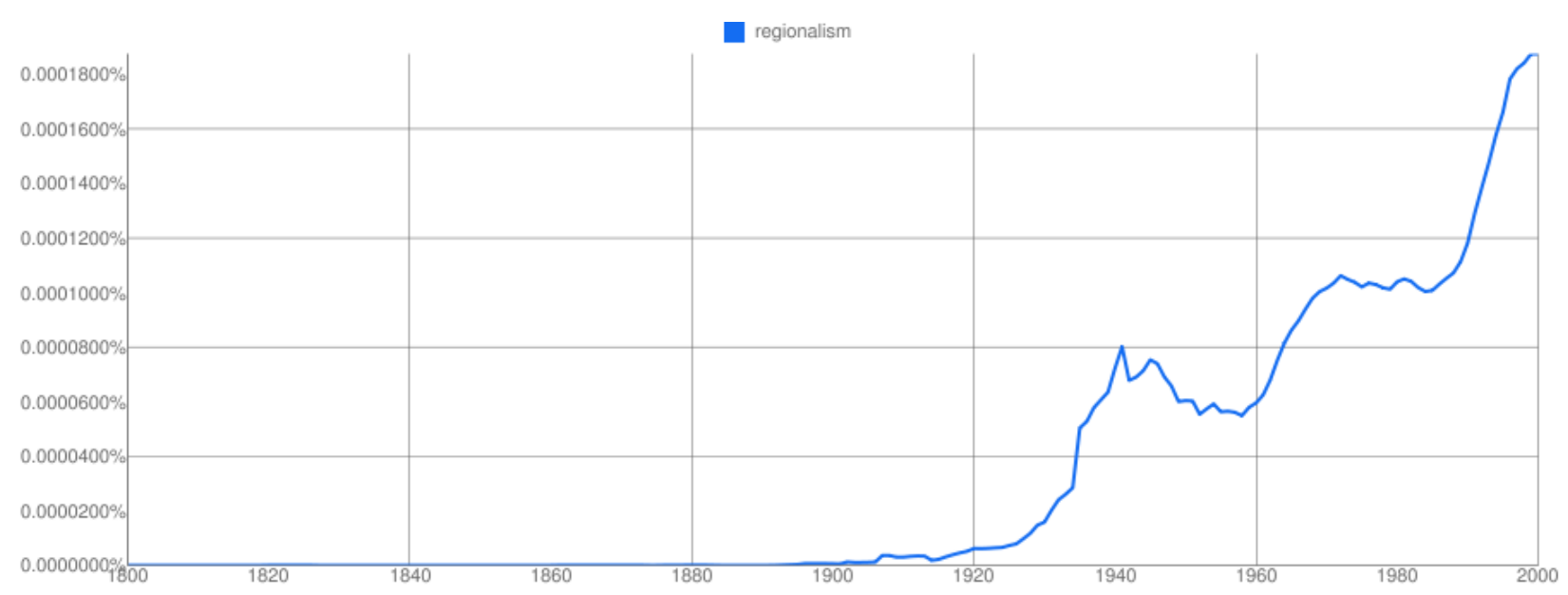

Figure 2. "Regionalism" Ngram, 1800-2000

Next, we reproduce the WTO's figures on the entry into force of RTAs in the 1948-2010 period in Figure 3.

5

http://ngrams.googlelabs.com/graph?content=regionalism\&year start=1800\&year end=2000\&corpus=0\&smooth ing $=3$ 


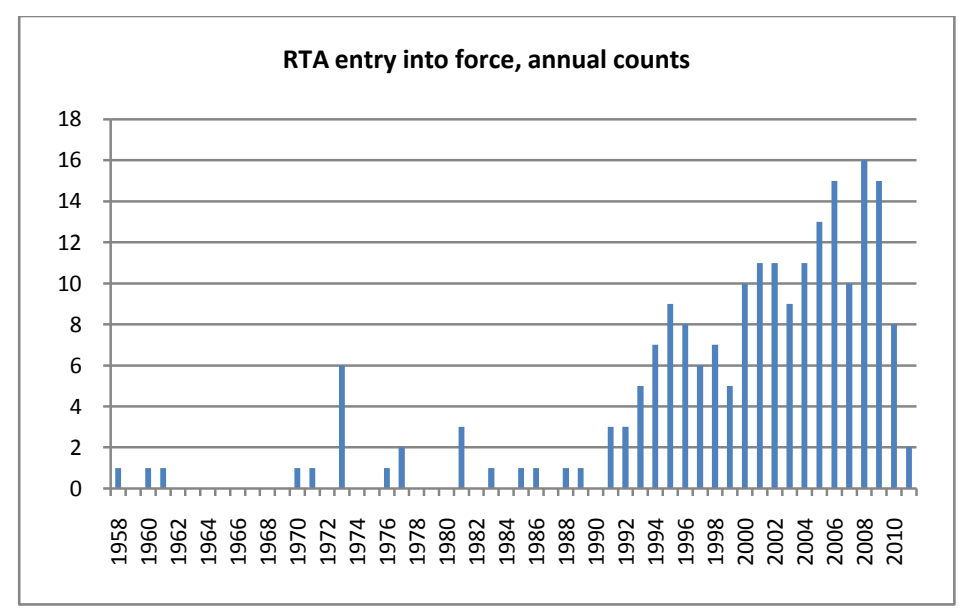

Figure 3. RTA entry into force ${ }^{6}$

We have been unable to obtain the numeric data underpinning the Google Ngram, so for now we have to content ourselves with visual inspection of the relationship between these trends, with a special view toward establishing the priority of discursive changes over institutional changes. We cannot definitively do so, but we do find the relationship suggestive. Leaving aside the prewar discussion of regionalism, we note about a 60\% increase in bibliographic references to regionalism between 1960 and about 1985, which occurs prior to the inflection in RTAs taking pace from the early 1990s. While we obviously cannot draw strong conclusions from this very informal analysis, we certainly find the priority of discursive change suggestive of, or at least consistent with, a world polity story in which rationalized, scientized elites placed the institutional form of regionalism into the global cultural script, which then produced isomorphic change. Based on this cursory view, we cannot reject hypothesis 1.

\section{B. Hypotheses 2 and 3}

Having asserted and provided suggestive evidence that the script of modernity has been modified over time to include lines about regionalism, we now turn to variation across actors, with special attention on less developed countries. Hypothesis 2 focuses on exposure to global cultural carriers, while hypothesis 3 focuses on the role of problematic identity. As these increase, so too should embrace of regionalism. We test these factors together in a minimally controlled OLS model in which a

\footnotetext{
${ }^{6}$ Source: WTO.
} 
count of the number of a country's PTA/RTA memberships in 2009 represents the dependent variable. Presumably, trading states, rich states, and democracies (Mansfield, Milner and Pevehouse 2008) should be more likely to agree to such arrangements, so we include controls for trade as a percentage of GDP, GDP per capita, and polity score. We also include a measure of stateness from the Bertelsmann Transformation Index (BTI) to control for state capacity to sign agreements and enter them into force. We expect all of these measures to be positively signed.

The variable of key theoretical interest in assessing hypothesis 3 is "political globalization" from the KOF Swiss Economic Institute. This measure is problematic insofar as it includes international treaties and IGO memberships among its components. We can only reiterate that our analysis is wholly exploratory, and moving forward we would like to isolate more direct factors that would better tap exposure to global cultural carriers. In any case, we again expect a positive sign on this variable. For hypothesis 2, our key indicator is years since independence. We suggest that more recent entrants into the world society will have greater need for the postulated identity benefits offered by regional trade agreements, and therefore expect a negative sign on the coefficient for this variable. We present separate regressions for PTA and RTA formation in an effort to isolate any aspects that might distinguish regionalism from its less constraining analog.

\section{PTA Membership, 2009}

\begin{tabular}{ll}
\hline Variable & Coefficient \\
\hline GDP per capita & $.00^{* *}$ \\
Years since independence & $-.02^{\sim}$ \\
Political globalization & $.15^{*}$ \\
Stateness & $2.69^{*}$ \\
Trade as percentage of GDP & .08 \\
Polity & .05 \\
Constant & -26.70 \\
\hline $\mathrm{N}$ & 83 \\
$\mathrm{R}^{2}$ & .52 \\
Adj. $\mathrm{R}^{2}$ & .49 \\
\hline
\end{tabular}

- *Significant at .01 level

- $\quad * *$ Significant at .05 level

- Significant at .10 level 
RTA Membership, 2009

\begin{tabular}{ll}
\hline Variable & Coefficient \\
\hline GDP per capita & $.00^{*}$ \\
Years since independence & $-.01^{*}$ \\
Political globalization & $.04^{*}$ \\
Stateness & $.69^{*}$ \\
Trade as percentage of GDP & .02 \\
Polity & .01 \\
Constant & -5.81 \\
\hline $\mathrm{N}$ & 83 \\
$\mathrm{R} 2$ & .45 \\
Adj R2 & .41 \\
\hline
\end{tabular}

- *Significant at .01 level

- ** Significant at .05 level

- Significant at .10 level

While we hasten to reiterate that this analysis is only exploratory, we do find the results to be suggestive of a world polity logic. Because of the construction problems with the political globalization measure as it relates to PTA/RTA membership, we will only note in passing that it is correctly signed and statistically significant in both models, providing very preliminary support for hypothesis 2 . More noteworthy, we think, is the "years since independence" measure. As expected, it is negatively signed: newly independent countries are more likely to join PTAs and RTAs, other things being equal. This effect is statistically significant at conventional levels for both institutional forms, albeit only at $p<.10$ for PTAs. The substantive effect is small but probably not trivial: an extra decade of independent statehood reduces RTA memberships by $10 \%$. Overall, this very preliminary analysis allows us to reject the null hypothesis that PTA/RTA memberships are unrelated to exposure to global cultural carriers and the need for legitimacy.

\section{Hypothesis 4}

Hypothesis 4 states that actors with problematic identities will be most vigorous in promoting their own models within the world polity. We of course have the EU in mind with this hypothesis, which was not constructed independently of almost any evidence that we might bring to bear. Since at least 
$1995,{ }^{7}$ and continuing into recent years, ${ }^{8}$ the EU is quite upfront about the fact that it seeks to promote regionalism, especially among LDCs.

Further, we would simply note the striking pattern revealed in Figure 4:

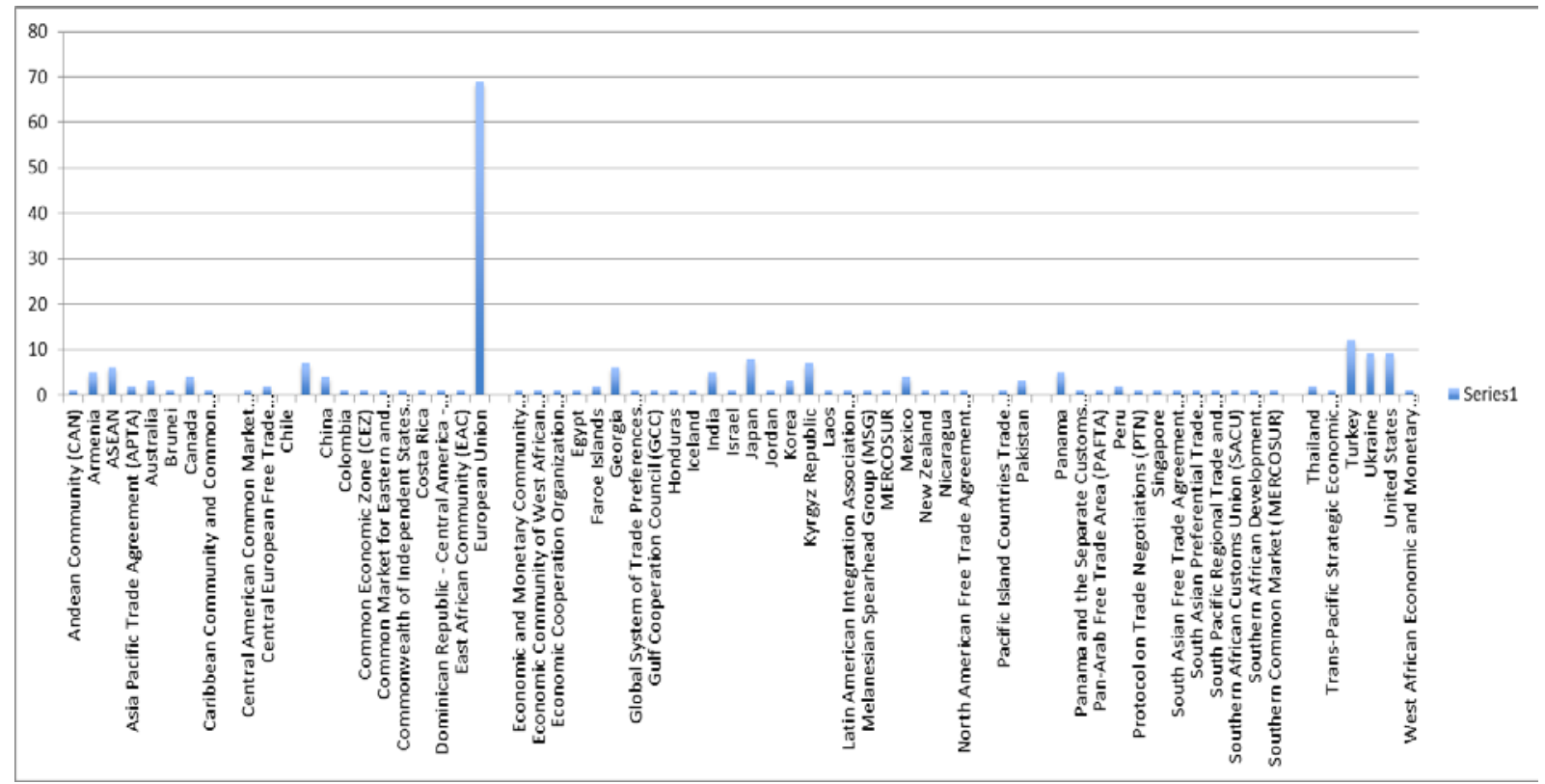

Figure 4. RTAs by signatory

The European Union is a signatory to 69 of the 289 PTAs in force and represented in these data, far and away the most active in this field. Furthermore, as Horn, Mavroidis and Sapir (2009) so exhaustively demonstrate, the EU differs radically from the United States in its approach to PTAs. The US tends to keep them simple and focused on trade liberalization. The EU lards its PTAs with non-economic, "WTOextra" considerations, even though these are almost entirely unenforceable. According to Pisani-Ferry's summary of this work (2009, p. vii), it seems that the EU "sees durable benefit in the generalisation of policy regimes inspired by its own," and this to a much greater degree than the other major hub in the world trading system, the US.

D. Summary

\footnotetext{
${ }^{7}$ E.g., $\operatorname{COM}(1995)$ 0219, European Community support for regional economic integration efforts among developing countries, June 16, 1995.

${ }^{8}$ E.g., COM(2008) 0604; SEC(2008) 2538; SEC(2008) 2539.
} 
Our purpose in this section has been to explore empirically some of the implications of world polity theory for the variable spread of regionalism over time and across actors. This exercise is primarily illustrative, intended to highlight some of the possibilities. This exploration increases our confidence on the power of world polity theory to account for some of the most important attributes of contemporary regionalism.

\section{Conclusion}

Regionalism is only the latest example of isomorphic institutional change in the world polity. Nearly everywhere, states are signing preferential and regional trade agreements. While we have not engaged the literature addressing the economic effects of regionalism, we do hold a skeptical view that it will accomplish its stated goals of trade liberalization, economic growth and social development among those actors that adopt it. If regionalism is not functional in this sense, why is it becoming so widespread? Most existing accounts take for granted that regionalism pursues these ends to which it is said to be directed. We argue, instead, that regionalism reflects the imperatives of actorhood in a world polity in which actors are broadly "scripted" to embrace certain legitimated goals through isomorphic institutional arrangements. Regionalism, in short, is increasingly seen as the legitimate and appropriate "thing to do," even while it is billed as an effective way of achieving more concrete ends.

We have argued that regionalism now forms a part of the "script of modernity" which all legitimate actors must enact; that actors with problematic identities will be the most voracious consumers of global scripts, as a substitute source for the legitimacy that they otherwise act; and that this will manifest itself both in the promotion of regionalism by actors such as the EU and in its embrace by less developed countries (LDCs). We have identified some working hypotheses that might account for temporal and cross-actor variation, and provided some empirical explorations aimed at initially checking them. 
Our aim has been primarily theoretical. The next steps would obviously involve the elaboration and specification of alternative accounts and systematic empirical testing. Two decades into the "new regionalism," we still understood too little about what has driven this seismic institutional change in the international trade regime. Remedying this shortcoming will not only improve our understandings of development and international economic institutions. It also promises to lay bear some of the basic premises of legitimate actorhood in the world polity, a status to which all states, and increasingly the European Union alongside them, aspire.

\section{REFERENCES AND SOURCES}

Beckfield, Jason. 2003. Inequality in the World Polity: The Structure of International Organization. American Sociological Review 68 (3): 401-20.

Bicchi, Federica. 2006. 'Our size fits all': normative power Europe and the Mediterranean. Journal of European Public Policy 13, 2 (March): 286-303.

Boli, John, 1987. World Polity Sources of Expanding State Authority and Organization, 1870-1970. In Thomas et al. 1987, pp. 71-91.

Boli, John, and George M. Thomas, eds. 1999. Constructing World Culture: International Nongovernmental Organizations Since 1875. Stanford: Stanford University Press.

Boli, John. 1999. Conclusion: World Authority Structures and Legitimations. In Boli and Thomas 1999, pp. 267-300.

Bull Hedley. 1995 [1977]. The Anarchical Society: A Study of Order in World Politics, 2nd edition. New York: Columbia University Press.

Chayes, Abram, and Antonia Handler Chayes. 1995. The New Sovereignty: Compliance with International Regulatory Agreements. Cambridge, MA: Harvard University Press.

Choi, Y.J. and James Caporaso. "Comparative Regional Integration." In Handbook of International Relations, by W., Thomas Risse, and Beth A. Simmons, eds. Carlsnaes, 480-499. London: Sage, 2002.

Claude, Inis L., Jr. 1966. Collective Legitimization as a Political Function of the United Nations. International Organization 20, 3 (Summer): 367-379.

Copenhagen European Council. "European Parliament." European Union. June 21-22, 1993. http://www.europarl.europa.eu/enlargement/ec/pdf/cop_en.pdf (accessed November 22, 2010). 
Costea, Ana-Cristina, and Luk Van Langenhove. 2007. EU's Foreign Policy Identity: from 'New Regionalism' to Third Generation Regionalism? In European Union Identity: Perceptions from Asia and Europe, edited by Jessica Bain and Martin Holland, 86-104. Baden-Baden: Nomos Verlagsgesellschaft.

DiMaggio, Paul J., and Walter W. Powell. 1983. The Iron Cage Revisited: Institutional Isomorphism and Collective Rationality in Organizational Fields. American Sociological Review 48, 2 (April): 147-160.

Doidge, Mathew. 2007. Joined at the Hip: Regionalism and Interregionalism. European Integration 29, 2 (May): 229-248.

Drori, Gili S., and Georg Krücken. 2009. World Society: A Theory and Research Program in Context. In Krücken and Drori 2009, pp. 3-35.

Ethier, WIlfrd J. "Regionalism in a Multilateral World." The Journal of Political Economy 106, no. 6 (1998): 1214-1245.

Ethier, Wilfrd, J. "The New Regionalism." The Economic Journal 108, no. 449 (1998): 1149-1161.

Farrell, Mary. 2005. EU External Relations: Exporting the EU Model of Governance? European Foreign Affairs Review 10: 451-462.

Feenstra, Robert C., James M. Markusen, and Andrew K. Rose. "Using the gravity equation to differentiate among alternative theories of trade." Canadian Journal of Economics 34, no. 2 (2001): 430-447.

Finnemore, Martha, and Kathryn Sikkink. 2001. Taking Stock: The Constructivist Research Program in International Relations and Comparative Politics. Annual Review of Political Science 4: 391-416.

Fiorentino, Robert V., et al. 2007. The Changing Landscape of Regional Trade Agreements: 2006 Update. Discussion Paper no. 12. Geneva: Regional Trade Agreements Section, Trade Policies Review Division, World Trade Organization.

Franck, Robert M. 1990. The Power of Legitimacy Among Nations. Oxford: Oxford University Press.

Goffman, Erving. 1959. The Presentation of Self in Everyday Life. New York: Anchor Books.

Grugel, Jean B. 2004. New Regionalism and Modes of Governance: Comparing US and EU Strategies in Latin America. European Journal of International Relations 10 (4): 603-626.

Horn, Henrik, Petros C. Mavroidis, and André Sapir. 2009. Beyond the WTO? An Anatomy of EU and US Preferential Trade Agreements, Bruegel Blueprint vol. 8. Brussels: Breugel.

Jackson, Robert H. 1987. Quasi-States, Dual Regimes, and Neoclassical Theory: International Jurisprudence and the Third World. International Organization 41, 4 (Autumn): 519-549. 
Jackson, Robert H. 1990. Quasi-States: Sovereignty, International Relations and the Third World. Cambridge: Cambridge University Press.

Jackson, Robert H., and Carl G. Rosberg. 1982. Why Africa's Weak States Persist: The Empirical and the Juridical in Statehood. World Politics 35 (October): 1-24.

Krücken, Georg, and Gili S. Drori, eds. 2009. World Society: The Writings of John W. Meyer. Oxford: Oxford University Press.

Lankowski, Carl. 2010. Remarks on EU Politics and Foreign Policy. Patterson School of Diplomacy and International Commerce, Fall Conference 2010: The European Union 2020," Lexington, KY, October 22.

Mansfield, Edward D. and Helen V. Milner. 1999. The New Wave of Regionalism. International Organization 53, no. 3: 589-627.

Mansfield, Edward D., and Helen V. Milner. 2008. Democracy, Veto Players, and the Depth of Regional Integration. World Economy 31, 1 (January): 67-96.

McNeely, Connie L. 1995. Constructing the Nation-State: International Organization and Prescriptive Action. Westport, CT: Greenwood Press.

Meyer, John W. 1987. The World Polity and the Authority of the Nation-State. In Thomas et al. 1987, pp. 41-70.

Meyer, John W. 1995. Foreword. In McNeely 2005, pp. ix-xiv.

Meyer, John W. 2009 [2000]. Globalization: Sources and Effects on National States and Societies. In Krücken and Drori 2009, pp. 156-169.

Meyer, John W. 2009. Reflections: Institutional Theory and World Society. In Krücken and Drori 2009, pp. 36-66.

Meyer, John W. 2010. World Society, Institutional Theories, and the Actor. Annual Review of Sociology 36: 1-20.

Meyer, John W., and Brian Rowan. 2009 [1977]. Institutionalized Organizations: Formal Structure as Myth and Ceremony. In Krücken and Drori 2009, pp. 89-110.

Meyer, John W., and Ronald L. Jepperson. 2009 [2000]. The 'Actors' of Modern Society: The Cultural Construction of Social Agency. In Krücken and Drori 2009, pp. 111-135.

Meyer, John W., et al. [David John Frank, Ann Hironaka, Evan Schofer, and Nancy Brandon Tuma]. 1997b. The Structuring of a World Environmental Regime, 1870-1990. International Organization 51, 4 (Autumn): 623-651. 
Meyer, John W., et al. [John Boli, George M. Thomas, and Francisco O. Ramirez]. 1997a. World Society and the Nation-State. American Journal of Sociology 103, 1 (July): 144-181

Meyn, Mareike. 2008. Economic Partnership Agreements: A ‘Historic Step' Towards a 'Partnership of Equals'? World Development Review 26 (5): 515-528.

Shibutani, Tamotsu. 1986. Social Processes: An Introduction to Sociology. Berkeley: University of California Press.

Strang, David, and John W. Meyer. 2009 [1993]. Institutional Conditions for Diffusion. In Krücken and Drori 2009, pp. 136-155.

Thomas, George, et al., eds. 1987. Institutional Structure: Constituting State, Society and the Individual. Beverly Hills, CA: Sage Publications.

United Nations Conference on Trade and Development (UNCTAD). 2007. Trade and Development Report 2007: Regional Cooperation for Development. New York and Geneva: United Nations.

Viner, Jacob. 1950. The Customs Union Issue. Washington, DC: Carnegie Endowment.

Whalley, John. Recent Regional Agreements: Why so many, so fast, so different and where are they headed? Working Paper No. 9, Waterloo, Ontario, Canada: The Centre for International Governance Innovation, 2006. 